\title{
Synaptic Facilitation at Connections of Hermissenda Type B Photoreceptors
}

\author{
Erin M. Schuman and Gregory A. Clark \\ Program in Neuroscience, Psychology Department, Princeton University, Princeton, New Jersey 08544
}

The enhancement of excitability in type B photoreceptors is an important neural mechanism underlying classically conditioned suppression of phototaxis in the marine mollusk Hermissenda crassicornis. However, the possibility that type B photoreceptors also exhibit synaptic plasticity has not previously been explored. We now report that connections of type B photoreceptors onto type A photoreceptors exhibit synaptic facilitation, and that this facilitation involves the same first messenger (5-HT) and second messenger (protein kinase $\mathrm{C}$ ) previously implicated in the learning-produced excitability changes. In brief, we found that application of 5HT dramatically facilitates synaptic potentials evoked by type B cells in type A cell cells, and that this facilitation is blocked by preincubation with staurosporine, a protein kinase inhibitor. Furthermore, activation of protein kinase $\mathbf{C}$ also induces synaptic facilitation, whereas activation of the cAMP-dependent protein kinase has no effect. Changes in synaptic strength produced by these manipulations are paralleled by changes in type $B$ cell input resistance (a simple index of cellular excitability), whereas type $A$ cell input resistance is unaffected. These findings indicate a previously unrecognized form of neuronal plasticity in Hermissenda that may contribute importantly to the learned changes in behavior, and thereby highlight general principles of learning-related neuronal plasticity shared by different preparations and species.

[Key words: Hermissenda, Aplysia, neuronal plasticity, learning, memory, 5-HT, protein kinase C, cAMP, staurosporine, phorbol ester]

The last decade has witnessed extraordinary progress in our understanding of the biological mechanisms underlying learning. Many of the advances occurring at the cellular and molecular level have come about through the use of invertebrate preparations, which have relatively simple nervous systems and large, identifiable neurons of known function (Carew and Sahley, 1986; Byrne, 1987; Hawkins et al., 1987). One goal of using such model systems has been to delineate general cellular principles of neuronal plasticity that are common to different preparations and are phylogenetically conserved.

Received Sept. 11, 1992; revised Iuly 2, 1993; accepted Aug. 26, 1993.

This research was supported by the Office of Naval Research Grant N00001489J-1954, a Pew Biomedical Scholars award, and an Alfred P. Sloan research fellowship to G.A.C. We thank E. R. Kandel and D. V. Madison for comments on an earlier version of the manuscript, and A. Kronewitter for secretarial assistance.

Correspondence should be addressed to Dr. Gregory A. Clark, Psychology Department, Green Hall, Princeton University, Princeton, NJ 08544.

Copyright (C) 1994 Society for Neuroscience $0270-6474 / 94 / 141613-10 \$ 05.00 / 0$
A particularly fruitful paradigm for the analysis of associative learning in an invertebrate is conditioned suppression of phototactic behavior in the marine mollusk Hermissenda crassicornis (Alkon, 1974; Crow and Alkon, 1978; Farley and Alkon, 1982; Crow, 1983; Crow and Offenbach, 1983; Lederhendler and Alkon, 1987). Naive Hermissenda normally locomote toward light. However, following pairings of light (the conditioned stimulus, or CS) and rotation (the unconditioned stimulus, or US), this normally positive phototactic behavior of the animal is suppressed. In contrast, control animals receiving unpaired or random presentations of the CS and US do not show comparable long-term suppression, though some smaller, transient nonassociative effects exist (Alkon, 1974; Crow and Alkon, 1978; Farley and Alkon, 1982; Crow, 1983). Associative training also leads to the emergence of a new conditioned response to the light CS that resembles the unconditioned response to the rotation US: whereas naive and random control animals exhibit foot lengthening in response to light, animals that received paired training exhibit foot shortening, similar to that evoked by rotation itself (Lederhendler et al., 1986; Matzel et al., 1990b).

Physiological investigations by Alkon, Crow, Farley and their colleagues have indicated that a pivotal mechanism underlying conditioning in Hermissenda is an intrinsic enhancement of excitability in the inhibitory type B photoreceptors (for reviews, see Farley, 1986; Crow, 1988; Alkon and Nelson, 1990). Following conditioning, type $\mathrm{B}$ cells exhibit depolarized membrane potentials, an increased input resistance, and an enhanced light response (Crow and Alkon, 1980; Farley and Alkon, 1982; West et al., 1982; Matzel et al., 1992a). These physiological changes arise largely from the modulation of two $\mathrm{K}+$ currents $\left(I_{\mathrm{A}}\right.$ and $I_{\mathrm{K}-\mathrm{Ca}}$ ) and possibly a $\mathrm{Ca}^{2+}$ current $\left(I_{\mathrm{Ca}}\right)$ (Alkon et al., 1982, 1985; Collin et al., 1988; Farley, 1988; Etcheberrigaray et al., 1992). Ultimately, the enhanced light response in type B cells translates into a suppression of phototactic behavior because the type $B$ photoreceptors inhibit type A photoreceptors and other neurons that have excitatory connections to motor circuitry mediating phototaxis (see Fig. 1; Alkon, 1979; Goh and Alkon, 1984; Goh et al., 1985).

Initial models proposed that changes in type B cells were induced by cumulative depolarization and subsequent $\mathrm{Ca}^{2+}$ influx that occurred during associative training; this depolarization was thought to arise from network interactions, including excitation of type $B$ cells by the silent/excitatory optic ganglion cell and release from inhibition by the caudal hair cells following the termination of light and rotation (Alkon, 1979, 1984; Tabata and Alkon, 1982; Farley and Alkon, 1987; Alkon and Nelson, 1990). However, more recent evidence suggests that cumulative depolarization may be neither necessary nor sufficient for the induction of type B cell excitability increases (Matzel et al., 
$1992 \mathrm{~b}$ ), and there is now general agreement that at least some of this plasticity is mediated by a neuromodulatory transmitter released by the US. The transmitter most strongly implicated is 5-HT, though GABA may also be involved. 5- $\mathrm{HT}$ is synthesized and released in the Hermissenda nervous system (Heldman and Alkon, 1978; Auerbach et al., 1989), and immunohistochemical studies have identified serotonergic neurons as well as scrotonergic processes in the synaptic neuropil near photoreceptor terminals (Land and Crow, 1985; Auerbach et al., 1989). Physiologically, serotonergic cells depolarize type B cells and respond to visual and vestibular stimulation (Cheyette and Farley, 1989), though it remains to be demonstrated that these response patterns can modify the activity of type $B$ cells, or that disabling these serotonergic cells disrupts the induction of type B plasticity. Exogenous application of 5-HT can produce a number of changes in type B cells similar to those seen following behavioral conditioning, including an enhanced light response, increased input resistance, depolarization, reduction of $I_{\mathrm{A}}$ and $I_{\mathrm{K}-\mathrm{Ca}}$, and increased spike amplitude (Crow and Bridge, 1985; Farley and Auerbach, 1986; Sakakibara et al., 1987; Farley and Wu, 1989; Crow and Forrester, 1991; Falk-Vairant and Crow, 1992; Rogers et al., 1992). Light paired with 5-HT also mimics the effect of conditioning on phototactic behavior (Crow and Forrester, 1986). In addition, drugs that disrupt 5-HT-mediated neurotransmission can block changes in type B cells produced by an in vitro conditioning paradigm involving paired light and hair cell stimulation (Grover et al., 1989). Taken together, these results provide evidence for a physiological and behavioral role for 5-HT during conditioning. More recently, GABA, a candidate transmitter for the hair cells, has also been found to induce an activity-dependent increase in input resistance in type B cells and to elevate intracellular $\mathrm{Ca}^{2+}$ (Matzel and Alkon, 1991; Alkon et al., 1992; Oka et al., 1992).

Protein kinase $\mathrm{C}$ (PKC) has been implicated as an important second messenger mediating conditioning-produced excitability changes in type B photoreceptors. Conditioning is associated with increases in the phosphorylation of PKC substrate proteins (Neary et al., 1981, 1986; Nelson et al., 1990) and changes in PKC activity (McPhie et al., 1993). Injection of PKC, or of a $20 \mathrm{kDa}$ PKC phosphoprotein, or activation of PKC by phorbol esters, all mimic effects of associative training, including enhancement of the light response, reductions of $I_{\mathrm{A}}$ and $I_{\mathrm{K}-\mathrm{Ca}}$, and enhancement of $I_{C a}$ in type B cells (Alkon et al., 1986, 1988; Farley and Auerbach, 1986; Etcheberrigaray et al., 1992). Reduction of PKC catalytic activity by either kinase inhibitors or downregulation of the holoenzyme can prevent both short-term changes in type B cell excitability (Forrester and Crow, 1988; Matzel et al., 1990a; Crow et al., 1991; Farley and Schuman, 1991) and long-term changes produced by behavioral training in the intact animal (Farley and Schuman, 1991). Crow and colleagues have proposed that with the in vitro paradigm that they have used, PKC is involved primarily in the induction of short-term changes (Forrester and Crow, 1988, 1989), suggesting that other second messengers may also contribute under certain conditions.

While much effort has been devoted to understanding the biophysical and molecular mechanisms underlying conditioning-produced increases in photoreceptor excitability, there has been no attempt to ascertain whether changes in synaptic transmission may also occur. Because synaptic plasticity is known to play an important role in learning and in other systems, such as classical conditioning in Aplysia (Hawkins et al., 1983; Wal- ters and Byrne, 1983; Carew et al., 1984), cerebellar long-term depression (Ito, 1989), and hippocampal long-term potentiation (Madison et al., 1991), the goal of this study was to assess its possible contribution in Hermissenda. To this end, we have asked whether connections of type B photoreceptors onto type A photoreceptors exhibit synaptic facilitation in addition to the increases in type B cell excitability previously described, and whether this facilitation involves the same neuromodulatory transmitter system $(5-\mathrm{HT})$ and the same second-messenger pathway $(\mathrm{PKC})$ that produce the excitability changes.

Preliminary reports of some of these findings have previously appeared (Schuman and Clark, 1990; Clark and Schuman, 1992).

\section{Materials and Methods}

Animals. Hermissenda crassicornis were obtained from Marinus, Inc. (Long Beach, CA). Animals were individually housed in perforated 50 $\mathrm{ml}$ tubes maintained in $12^{\circ} \mathrm{C}$ artificial seawater (ASW).

Electrophysiology. The circumesophageal nervous system (containing the eyes, plus the cerebral, pleural, and pedal ganglia) was dissected from a naive animal and mounted on a glass slide as previously described (Farley and Alkon, 1982), and treated with a nonspecific protease (protease type XXVII, $1.5 \mathrm{mg} / \mathrm{ml}$ ASW; Sigma, St. Louis, MO) for 10 min to facilitate intracellular impalement.

Except as indicated below, during experiments preparations were bathed in ASW with the following composition (in $\mathrm{mM}$ ): $\mathrm{NaCl}, 430$; $\mathrm{KCl}, 10 ; \mathrm{CaCl}_{2}, 10 ; \mathrm{MgCl}_{2}, 50$; Tris $\cdot \mathrm{HCl}$ buffer $(\mathrm{pH} 7.6), 10$. The ASW $\mathrm{pH}$ was adjusted to 7.6. A type B photoreceptor and type A photoreceptor with a reliable synaptic connection were identified (Fig. 1) using conventional intracellular recording and stimulation with glass microelectrodes containing $2 \mathrm{M} \mathrm{K}$-acetate. Type B cells could be distinguished from type A cells by their position and by several physiological characteristics, including spontaneous action potential activity in the dark, as well as size and shape of the action potentials (Alkon, 1976). Based on the position of the microelectrodes prior to impalement, the majority of photoreceptor pairs used in this study were most likely an intermediate type $\mathrm{B}$ cell and a lateral type A cell.

Following cell impalement, preparations were dark adapled for 10 min. We then elicited single action potentials in type B cells via intracellular stimulation at $30 \mathrm{sec}$ intervals, and recorded the resulting inhibitory postsynaptic potential (IPSP) in the type A photoreceptor. As a simple index of cellular excitability, we also measured the initial input resistance of both cells using $0.1-0.4 \mathrm{nA}$ hyperpolarizing steps. For each preparation, IPSP and input resistance measurements were obtained for the five trials before (pre) and the 10 trials after (post) one of the following six experimental treatments: (1) control exchange of ASW; (2) bath application of $1 \mu \mathrm{M}$ 5-HT (Sigma); (3) bath application of $1 \mu \mathrm{M} 5-\mathrm{HT}$, following pretreatment with, and continued exposure to, the protein kinase inhibitor staurosporine $(0.1 \mu \mathrm{M}$; Sigma), which was initially applied prior to cell impalement and kept present throughout the experiment; (4) bath application of $0.1 \mu \mathrm{M}$ phorbol 12-myristate 13-acetate (PMA; Sigma), which activates PKC; (5) bath application or the inactive phorbol ester 4- $\alpha$ phorbol $(0.1 \mu \mathrm{M}$; Sigma); or (6) bath application of $100 \mu \mathrm{M}$ 8-benzylthio-cAMP (8-BT-cAMP) (ICN Biochemicals, Cleveland, $\mathrm{OH}$ ), a membrane-permeant cAMP analog that activates the cAMPdependent kinase, in combination with the phosphodiesterase inhibitor 3 -isobutyl-1-methyl-xanthine (IBMX; $100 \mu \mathrm{M}$; Sigma). A 5-10 min incubation period was allowed following the experimental solution exchange before the IPSP and input resistance were remeasured. Solution changes were performed by hand-held pipette and involved several changes in bath volume. In accordance with standard practice, throughout the experiment the baseline membrane potential of type A and type $B$ photoreceptors was held constant at -60 to $-70 \mathrm{mV}$ (a value that is below action potential threshold) by manually varying the holding current. This manipulation was performed in order to prevent spontaneous action potential generation and to minimize possible secondary influences of any drug-induced changes in membrane potential on the IPSP size and input resistance, as both of these measures are sensitive to membrane potential. We did not systematically investigate the effects of our experimental manipulations on membrane potential, though previous work on 5-HT and PKC suggests that such changes do occur (Alkon et al., 1986, 1988; Farley and Auerbach, 1986; Farley and $\mathrm{Wu}$, 1989; Rogers et al., 1992). 
Statistical analysis. For each preparation, the mean IPSP amplitude and mean input resistance of type A and type B cells were computed for the five trials immediately preceding the solution change (pretreatment score), and for the 10 trials immediately after the solution change (posttreatment score). Statistical analyses were then performed using a one-way ANOVA, followed by either two-tailed $t$ tests for related means for within-group effects (e.g., pretreatment vs posttreatment), or Newman-Keuls planned comparisons for between-group effects. There were no significant changes in IPSP amplitude across the five pretreatment trials for any of the six experimental conditions, indicating that our testing protocol did not strongly affect synaptic strength or general cell health.

\section{Results}

5-HT produces synaptic facilitation at type $B$ cell connections

Previous work had demonstrated that type B cells exhibit a learning-dependent increase in excitability (Crow and Alkon, 1980; Farley and Alkon, 1982; West et al., 1982; Matzcl ct al., 1992a) that appears to involve 5-HT (Crow and Bridge, 1985; Crow and Forrester, 1986, 1991; Farley and Auerbach, 1986; Sakakibara et al., 1987; Farley and $\mathrm{Wu}, 1989$; Grover et al., 1989; Falk-Vairant and Crow, 1992; Rogers et al., 1992). We therefore asked whether 5-HT might induce synaptic facilitation at connections of type $B$ cells, in addition to the excitability changes previously described. We found that acute application of 5-HT doubled the size of the IPSP elicited by the type B cells in the type A cells (mean \pm SEM: pre, $0.50 \pm 0.12 \mathrm{mV}$; post, $0.96 \pm 0.15 \mathrm{mV} ; n=15, t(14)=4.18, p<0.001$; Fig. 2). In contrast, sham exchanges with normal ASW produced no effect (pre, $0.55 \pm 0.17 \mathrm{mV}$; post, $0.45 \pm 0.16 \mathrm{mV} ; n=11, t(10)=$ 1.29, NS). As in previous work (Farley and Auerbach, 1986; Farley and $\mathrm{Wu}, 1989), 5-\mathrm{H}^{\prime}$ also caused a significant increase in the input resistance of the type B cell $(30.9 \pm 8.2 \%$ increase, $n=14, t(13)=3.78, p<0.005)$, consistent with a decrease in $\mathrm{K}^{+}$currents and increased excitability. Thus, 5-HT enhanced both IPSP amplitude and type $B$ cell input resistance. In contrast, 5-HT had no effect on type A cell input resistance $(4.4 \pm 6.2 \%$ increase, $n=15, t(14)=0.70, \mathrm{NS})$, indicating that increases in IPSP amplitude could not be accounted for by a general increase in postsynaptic input resistance (though other postsynaptic mechanisms are possible). There were no significant changes in input resistance of either type B cells $(8.4 \pm 11 \%$ decrease, $n=11, t(10)=0.77$, NS) or type A cells $(5.7 \pm 5.8 \%$ decrease, $n=11, t(10)=0.99, \mathrm{NS})$ following sham solution changes of normal ASW. These results demonstrate that connections of type B cells can exhibit synaptic facilitation, and that both synaptic facilitation and type B cell excitability increases can be elicited by the same neuromodulatory transmitter, 5-HT.

\section{The kinase inhibitor staurosporine blocks 5-HT-induced synaptic facilitation}

As described above, PKC is a critical second messenger underlying learning-induced increases in type B cell excitability. We therefore wished to determine whether PKC was involved in synaptic facilitation as well. We first examined whether preincubation with the protein kinase inhibitor staurosporine (preceding and during the 5-HT application) would block the synaptic facilitation normally produced by 5-HT. Staurosporine is a somewhat broad-spectrum kinase inhibitor that is most potent in its inhibition of PKC $\left(\mathrm{IC}_{50}=3 \mu \mathrm{M}\right.$; Tamaoki et al., 1986), but that, to a lesser extent, also inhibits the cAMP-dependent protein kinase and $\mathrm{Ca}^{2+} /$ calmodulin-dependent protein kinases

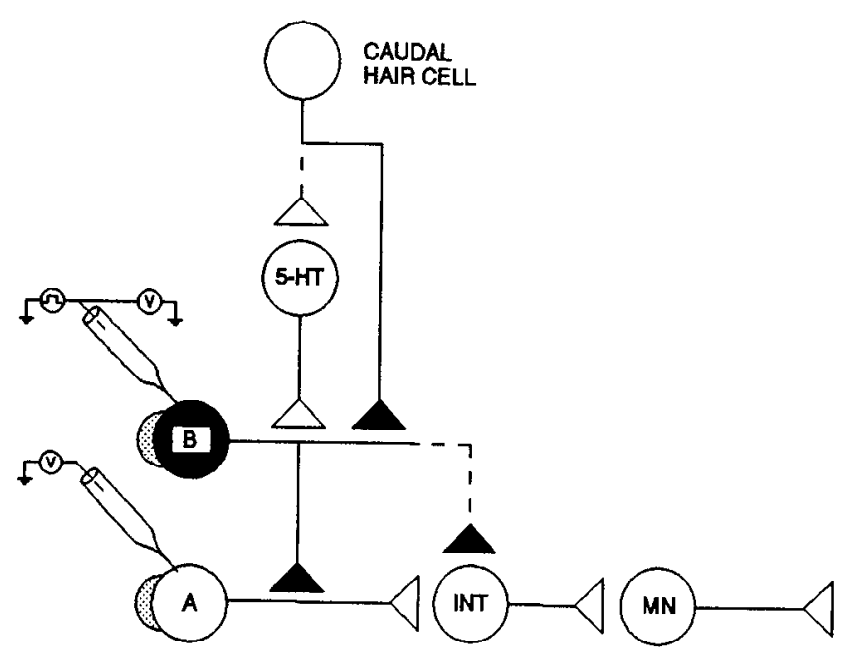

Figure 1. Experimental arrangement for examining synaptic facilitation at connections of type $B$ photoreceptors onto type A photoreceptors. In the present in vitro experiments, we examined the inhibitory postsynaptic potentials (IPSPs) elicited in type A photoreceptors by individual action potentials evoked by intracellular stimulation of type $B$ photoreceptors. In the intact animal, the inhibitory influences of the type B cells are believed to be responsible for the conditioned suppression of phototaxis. White triangles indicate excitatory synaptic connections; black triangles indicate inhibitory synaptic connections. Only selected relevant connections are depicted. The actual Hermissenda eye contains two type A and three type B photoreceptors, and each statocyst (the sensory organ for rotation) has 12 hair cells. The optic ganglion contains 13 second-order visual neurons (not depicted). Type A cells and type B cells inhibit each other, type B cells and caudal hair cells both inhibit the $\mathrm{S} / \mathrm{E}$ optic ganglion cells, and the $\mathrm{S} / \mathrm{E}$ cells excite type B photoreceptors and inhibit caudal hair cells (Alkon, 1979; Goh and Alkon, 1984; Goh et al., 1985). 5-HT, serotonin; INT, interneuron; $M N$, motor neuron.

(Ruegg and Burgess, 1989). We found that pretreatment with staurosporine blocked both the synaptic facilitation (pre, 0.68 $\pm 0.23 \mathrm{mV}$; post, $0.54 \pm 0.18 \mathrm{mV} ; n=11, t(10)=1.5$, NS) and the increased input resistance in type $B$ cells $(0.7 \pm 3.3 \%$ decrease, $n=11, t(10)=0.21$, NS) normally induced by 5 -HT (Fig. 2). Staurosporine has previously been shown to block depolarization and increased input resistance produced in type B cells by in vitro conditioning (Farley and Schuman, 1991), as well as spike broadening and synaptic facilitation produced by 5-HT in Aplysia sensory neurons (Sugita et al., 1992). We found no significant effect of staurosporine plus 5-HT on input resistance of type A cells $(1.6 \pm 5.1 \%$ decrease, $n=11, l(10)=0.32$ NS).

Between-group statistical comparisons indicated that 5-HT effects were significant relative to both the ASW condition and the staurosporine plus $5-\mathrm{HT}$ condition. An ANOVA $[F(2,34)$ $=11.0, p<0.001]$ followed by Newman-Keuls tests for individual comparisons indicated that the increase in IPSP amplitude following 5-HT treatment was significantly greater than changes in both the ASW group $(p<0.01)$ and the staurosporine plus 5-HT group ( $p<0.01$ ), which did not differ from each other. Similarly, changes in type B cell input resistance showed a reliable between-groups difference $[F(2,33)=6.2, p<0.01]$, with the increase in response to $5-\mathrm{HT}$ being significantly greater than changes in both the ASW group $(p<0.01)$ and the staurosporine plus 5-HT group $(p<0.01)$, which did not differ from each other. There were no significant between-group differences 
A.

ASW

TYPE A PHOTORECEPTOR
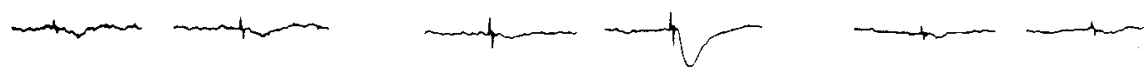

$\mathrm{mV}$

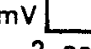

TYPE B PHOTORECEPTOR

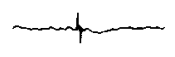

5-HT

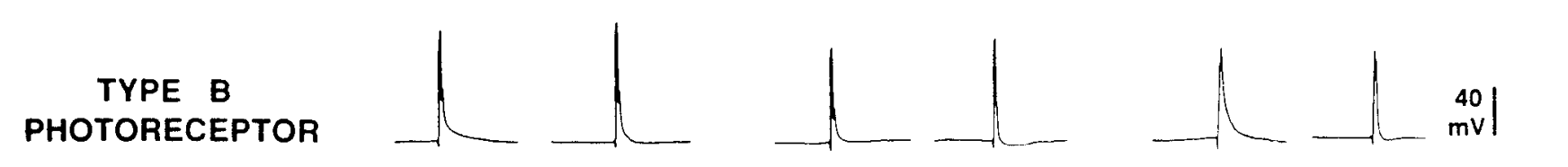

5-HT + STAURO.

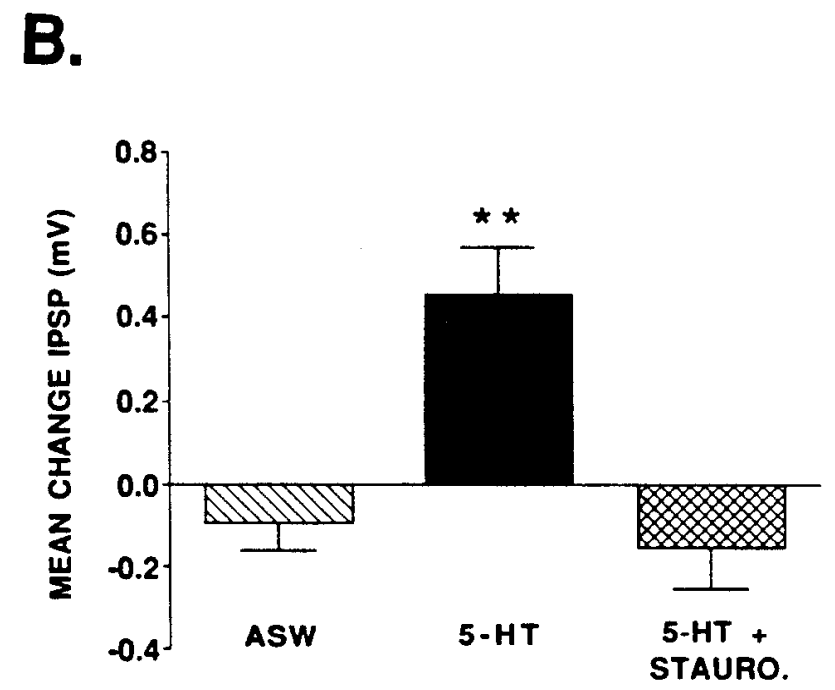

C.

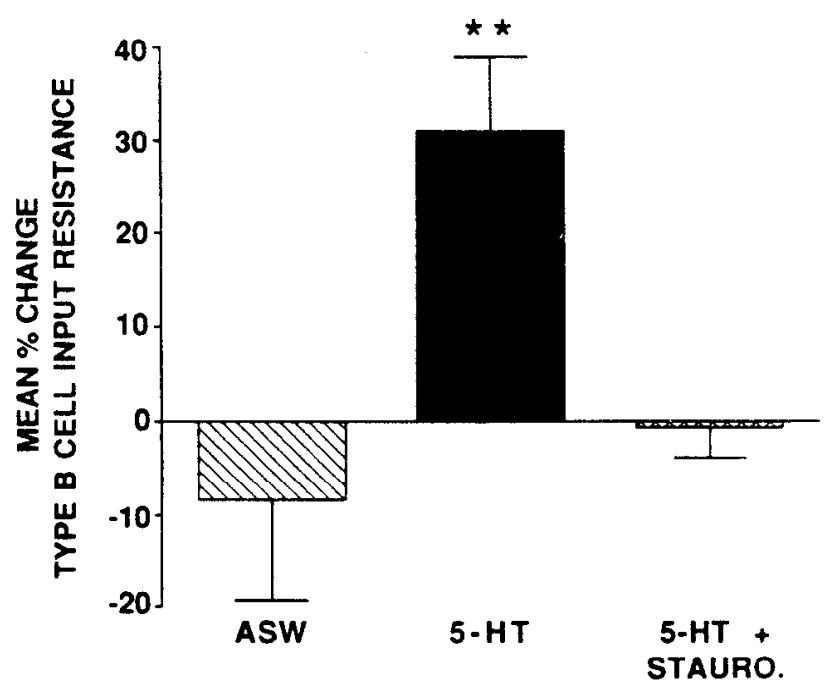

Figure 2. Acute application of 5-HT facilitates synaptic transmisssion at type B to type A photoreceptor synapses. $A$, Sample simultaneous recordings from type A photoreceptors (top traces) and type B photoreceptors (bottom traces) in three preparations, each receiving a different experimental treatment. Action potentials in type B cells were evoked by intracellular stimulation. Examples are from before (left) and after $(r i g h t)$ three different experimental treatments. Bath application of $1 \mu \mathrm{M} 5-I I T$ (middle traces) produced an immediate and dramatic enhancement of the IPSP elicited by the type $\mathrm{B}$ cell, whereas control preparations receiving exchanges of normal seawater ( $A S W$, left traces) showed relatively little change. In addition, preincubation with $0.1 \mu \mathrm{M}$ staurosporine (STAURO., right traces), an inhibitor of PKC, blocked the facilitation normally produced by 5-HT. The apparent large size of action potentials in the type B cells was due to the large depolarization necessary to evoke action potentials from hyperpolarized levels with somatic current injections; the size of spontaneous action potentials at the normal resting potential was consistent with type $\mathrm{B}$ cell physiology for this figure and subsequent figures. $B$, Group data indicating the mean change in IPSP amplitude. IPSP amplitude was increased following 5-HT but not the other two experimental treatments. $C$, Group data indicating increase in type B cell input resistance following 5-HT but not ASW or staurosporine plus 5-HT. Note that IPSP amplitude and type B cell input resistance covaried in response to the different experimental treatments. ${ }^{* *}, p<0.01$.

in the effects on type A cell input resistance $[F(2,34)=0.72$, NS). There were also no significant differences on any pretest measure between groups, including the staurosporine pretreatment condition, suggesting that staurosporinc did not affect the basal IPSPs or input resistance.

Taken together, these results indicate that 5-HT can produce both synaptic facilitation at type B cell connections and excitability increases in type B cells, and that activation of a kinase is a necessary component in the mechanism underlying both these effects.
Activation of PKC, but not the CAMP-dependent kinase, induces synaptic facilitation

Previous work had indicated that PKC could enhance type B cell excitability (Alkon et al., 1986, 1988; Farley and Auerbach, 1986; Etcheherrigaray et al., 1992), but its effect on synaptic transmission was unknown. Accordingly, we next investigated whether activation of PKC, or alternatively, activation of the cAMP-dependent kinase, would elicit synaptic facilitation at type $B$ cell connections. 
A.

4-ALPHA

TYPE A

PHOTORECEPTOR

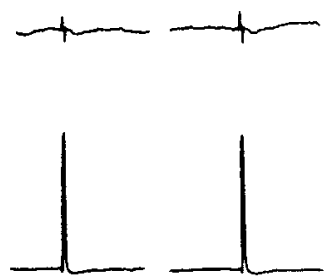

PMA
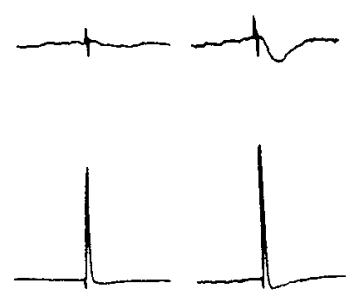

8-BT CAMP
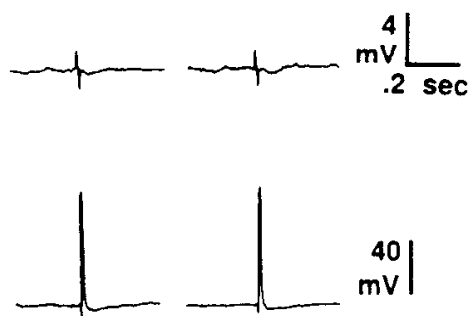
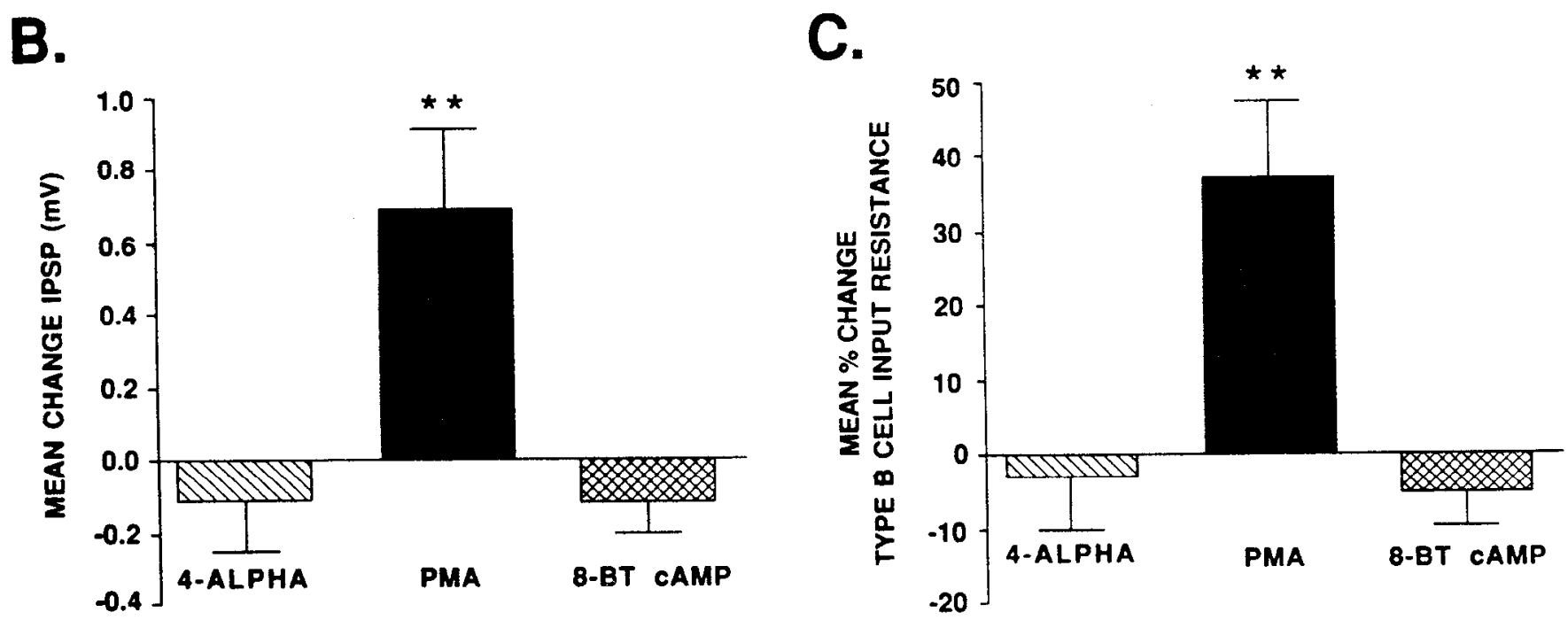

Figure 3. Activation of PKC, but not the cAMP-dependent protein kinase, facilitates synaptic transmission at type B to type A photoreceptor synapses. A, Sample intracellular recordings from type A photoreceptors (top traces) and type B photoreceptors (bottom traces) in three preparations, each receiving a different experimental treatment. Action potentials in type B cells were evoked by intracellular stimulation. Examples are from before (left) and after (right) application of either 0.1 $\mu \mathrm{M} 4-\alpha$ phorbol (an inactive phorbol ester), $0.1 \mu \mathrm{M} P M A$ (a phorbol ester that activates PKC), or $100 \mu \mathrm{M} 8-B T-c A M P$ (a membrane-permeant cAMP analog) given in combination with $100 \mu \mathrm{M}$ IBMX (a phosphodiesterase inhibitor). Note synaptic facilitation occurring after exposure to PMA, but not after the other two treatments. $B$, Group data indicating the mean change in IPSP amplitude following each of the experimental treatments. PMA produced a significant increase in IPSP amplitude; preparations receiving 4- $\alpha$ phorbol or 8-BT-cAMP plus IBMX showed no significant effects. C, Group data indicating mean change in input resistance of typc B photorcceptors. Like IPSP amplitude, type B cell input resistances were significantly increased following PMA, whereas there were no significant changes following application of $4-\alpha$ phorbol or 8-BT-cAMP plus IBMX. ${ }^{* *}, p<0.01$.

We found that application of the phorbol ester PMA, which activates $\mathrm{PKC}$, produced a marked facilitation in the amplitude of the IPSP evoked by type B cell stimulation (pre, $0.75 \pm 0.21$ $\mathrm{mV}$; post, $1.43 \pm 0.27 \mathrm{mV} ; n=13, t(12)=3.09, p<0.01)$ (Fig. 3). In contrast, neither the inactive phorbol ester 4- $\alpha$ phorbol nor the membrane-permeant cAMP analog 8-BT-cAMP had any significant effect on IPSP size (4- $\alpha$ phorbol: pre, $0.69 \pm$ $0.17 \mathrm{mV}$; post, $0.54 \pm 0.14 \mathrm{mV} ; n=10, t(10)=1.23$, NS; 8-BT-cAMP: pre, $0.65 \pm 0.13$; post, $0.54 \pm 0.13 \mathrm{mV} ; n=12$, $t(11)=1.28, \mathrm{NS})$. In addition, PMA increased the input resistance of type B photoreceptors, whereas the inactive 4- $\alpha$ phorbol and 8-BT-cAMP did not (PMA: $37.2 \pm 9.8 \%$ increase, $n=13$, $t(12)=3.79, p<0.005 ; 4-\alpha$ phorbol: $3.2 \pm 7.2 \%$ decrease, $n$ $=10, t(9)=0.44$, NS; 8-BT-cAMP: $5.4 \pm 4.6 \%$ decrease, $n=$
$12, t(11)=1.16, \mathrm{NS})$. None of the agents produced a significant change in the type A photoreceptor input resistance (PMA: 5.4 $\pm 5.3 \%$ decrease, $n=13, t(12)=1.02$, NS; $4-\alpha$ phorbol: $5.4 \pm$ $9.3 \%$ increase, $n=10, t(9)=0.58$, NS; 8 -BT-cAMP: $1.3 \pm 6.0 \%$ decrease, $n=12, t(11)=0.22$, NS). Thus, PMA, like 5-HT, enhanced both IPSP amplitude and type B cell input resistance.

These conclusions were also supported by between-group analyses. An ANOVA $[F(2,32)=7.9, p<0.005]$ followed by Newman-Keuls tests indicated that PMA produced a significant increase in IPSP amplitude relative to preparations receiving 4- $\alpha$ phorbol $(p<0.01)$ or 8-BT-cAMP plus IBMX $(p<0.01)$, while the latter two groups were not significantly different from one another. Similarly, type B cell input resistances following PMA were significantly increased $[F(2,32)=9.4, p<0.001]$ 
relative to changes following 4- $\alpha$ phorbol application $(p<0.01)$ or 8-BT-cAMP plus IBMX ( $p<0.01)$, while the latter two groups were not significantly different from one another. There were no significant between-group differences in the effects on type A cell input resistance $[F(2,32)=0.65, \mathrm{NS}]$, and no between-group differences on any measure prior to experimental treatment.

Taken together, these results indicate that activation of $\mathrm{PKC}$ augments synaptic strength at type B to type A photoreceptor synapses and enhances type $B$ cell input resistance, whereas activation of the cAMP-dependent kinase does not affect either measure.

\section{Discussion}

Connections of type $B$ photoreceptors exhibit synaptic facilitation

These results provide the first evidence that connections of $\mathrm{Her}$ missenda type B photoreceptors, which are known targets for learning-induced modifications in excitability, can exhibit synaptic facilitation. In addition, they indicate that these synaptic changes involve the same first messenger (5-HT) and second messenger (PKC) previously implicated in the enhancement of excitability. In brief, we found that both 5-HT and activation of PKC augmented IPSPs elicited by type B cells, whereas activation of the CAMP-dependent kinase had no effect. Moreover, the kinase inhibitor staurosporine blocked the induction of synaptic facilitation by 5-HT. In each case, the effect on synaptic strength was closely paralleled by the effect on type B cell input resistance, suggesting that the two forms of plasticity are mechanistically related.

\section{Effects on type A photoreceptors}

In contrast to the effects observed on type B input cells, none of our manipulations produced a reliable change in type A cell input resistance. This finding is of interest for two reasons. First, it indicates that the increase in synaptic strength that we observed cannot be attributed to a general increase in input resistance of the postsynaptic cell. Coupled with the modifications that did occur in type B cells, the lack of effect on type A cells thus suggests that this synaptic facilitation involves presynaptic mechanisms, though more direct demonstrations are certainly needed.

Second, these negative results are also of interest because behavioral conditioning produces excitability changes in type A cells that are reciprocal to those changes observed in type B photoreceptors, that is, decreased input resistances and reduced light responses (Farley and Alkon, 1982; Farley et al, 1990). The inability of 5-HT, PKC-activating phorbol esters, and 8-BTcAMP to alter type A photoreceptor input resistance thus suggests that other first- and second-messenger systems (distinct from 5-HT, PKC, and cAMP) may play a role in producing the type A cell excitability decreases observed with behavioral conditioning.

\section{Functional significance of synaptic facilitation in type $B$ cells}

Previous proposals have suggested that increases in the light response and excitability of type $B$ cells are causally involved in conditioned suppression of phototaxis in Hermissenda (Crow and Alkon, 1980; Farley and Alkon, 1982; West et al., 1982; Alkon, 1984), and computational models of neural circuitry explicitly lacking synaptic changes have recently been forwarded (Tesauro, 1988; Werness et al., 1992) proposing that excitability changes are necessary and sufficicnt to account for changes in behavior (Werness et al., 1992). Our findings that connections of type B cells exhibit synaptic facilitation indicate that synaptic plasticity also may contribute importantly to behavioral learning, as well as to the altered physiological responses observed in motor neurons and other cells downstream from photoreceptors (Farley and Alkon, 1982; Goh et al., 1985; Richards and Farley, 1987; Hodgson and Crow, 1992).

It will now be essential to determine whether synaptic facilitation can result from in vitro conditioning and behavioral conditioning in the intact animal and, if so, whether it is mediated by the mechanisms described herein. It will also be important to know whether synaptic facilitation can exist in a long-term form, in addition to the short-term plasticity we have described here, and whether synaptic plasticity can be associative in nature, as both the behavioral and excitability changes have been demonstrated to be. The fact that 5-HT and PKC-the cellular signals employed in the present studies to induce synaptic facilitation-have previously been implicated in changes in type $B$ cell excitability and behavior during conditioning in the intact animal (Crow and Forrester, 1986; Grover et al., 1989; Farley and Schuman, 1991) strongly suggests that synaptic plasticity may play a role in behavioral conditioning as well.

In further support of this possibility, following our initial report of synaptic facilitation (Schuman and Clark, 1990; Clark and Schuman, 1992), Frysztak and Crow have begun to examine effects of behavioral training on synaptic transmission between Hermissenda photoreceptors. Although they at first found no indication of synaptic facilitation in conditioned animals (Frysztak and Crow, 1991), more recently they have reported evidence that behavioral training can, in fact, strengthen connections from medial B onto medial A photoreceptors (Frysztak and Crow, 1994). One other study suggesting possible synaptic changes following conditioning is the recent description of a reduction of the terminal arborizations of type B cells (Alkon et al., 1990). Because the loss of synaptic contacts from these processes might be expected to result in a decrease (rather than the anticipated increase) of inhibitory type B cell influences, Alkon and colleagues suggested that there may have been a simultaneous but undetected anatomical augmentation in a restricted subset of relevant type B synapses. Our findings provide direct support that synaptic increases can indeed occur at type B connections.

In the present study, both synaptic strength and type B cell input resistance covaried in response to a variety of experimental manipulations, suggesting that these two forms of plasticity may share aspects of a common underlying mechanism. If so, these two forms of plasticity may also occur together in type B cells in intact animals. However, it is also plausible that some manipulations may produce one form of plasticity but not the other. Thus, the analysis of synaptic plasticity in type B cells may provide an additional means to explore learning mechanisms in Hermissenda. For example, synaptic plasticity may be able to account for phenomena that cannot be attributed to excitability increases. Similarly, studies of synaptic plasticity might further delineate the role of cellular activity, neuromodulatory transmitters, and second messengers in the modification of type B cells.

One further point merits mention. We wish to indicate quite explicitly that our findings of synaptic facilitation complement rather than contradict the excitability increases previously described. The two forms of plasticity are by no means mutually exclusive. Instead, we propose that the two mechanisms could 
work in concert to enhance behavioral learning. Increases in cellular excitability would produce an increase in number of action potentials elicited by a constant input, so that following conditioning, type $\mathrm{B}$ cells would fire more in response to the light CS. Concomitantly, increases in synaptic strength of type $B$ cells would increase transmitter release per action potential. Both forms of plasticity would cause type B cells to produce greater inhibition of their postsynaptic targets and, consequently, greater suppression of the normally positive phototactic responsc. In support of thesc idcas, we have recently begun to model quantitatively the contributions of these two forms of plasticity using Hodgkin-Huxley simulations of the type B cell, and have found that increases in type B cell synaptic strength and excitability can each enhance the functional inhibition of firing frequency in target photoreceptors (Fost and Clark, 1993). Finally, we might note that excitability changes in type B cells have previously been described as being postsynaptic*(Alkon, 1984) or nonsynaptic (Clark and Schuman, 1992), while here we propose that the synaptic facilitation we observed may involve presynaptic mechanisms. Because type B cells have both afferent and efferent synaptic connections and directly respond to light, each of these descriptions can accurately depict the functional consequences of type B cell changes with respect to other circuit elements.

\section{Contributions of 5-HT and PKC}

Our results indicate that 5-HT and PKC are important first and second messengers underlying synaptic facilitation at connections between type B and type A photoreceptors. Both 5-HT and PMA, a phorbol ester that activates $\mathrm{PKC}$, elicited synaptic facilitation, suggesting that 5-HT and PKC are each sufficient to induce facilitation. In contrast, the membrane permeant cAMP analog 8-BT-cAMP produced no facilitation, even though it was given at relatively high concentration and in conjunction with IBMX, a phosphodiesterase inhibitor that should potentiate its effect. We did not have a positive control for the activation of the cAMP-dependent kinase in these experiments, but similar protocols are effective in activating the cAMP-dependent kinase in other molluscan neurons (Frost et al., 1988; Schacher et al., 1988). Further support for the role of PKC comes from the observation that facilitation normally induced by 5-HT was blocked by staurosporine. While staurosporine is a relatively broad-spectrum kinase inhibitor, its affinity is greater for PKC than for other kinases (Tamaoki et al., 1986; Ruegg and Burgess, 1989). Taken together, these results suggest that activation of PKC is a necessary and sufficient step in the induction of synaptic facilitation at type $\mathrm{B}$ cell connections by $5-\mathrm{HT}$.

In previous work described above, 5-HT and $\mathrm{PKC}$ have been strongly implicated in type B cell excitability increases as well as in behavioral learning. Corroborating earlier observations (Farley and Auerbach, 1986; Farley and Wu, 1989), we found that 5-HT and PKC activation by PMA increased input resistance of type B cells (a simple measure of excitability) in addition to enhancing synaptic strength. Similarly, manipulations that did not produce synaptic facilitation (e.g., application of 8-BTcAMP and application of the kindse inhibitor staurosporine in conjunction with 5-HT) also did not increase input resistance of type B cells. Thus, effects of our manipulations on input resistance tracked the effects on synaptic strength. These findings suggest that increases in type B cell synaptic strength and excitability share a common first messenger (5-HT) and common second messenger (PKC).
Recently, other transmitters such as GABA have also been proposed to be involved in the modulation of type $B$ cell excitability, presumably by activating PKC (Matzel and Alkon, 1991; Alkon et al., 1992; Oka et al., 1992). Further work will be necessary to determine the relative contributions of these and other possible neuromodulatory transmitters to behavioral and neuronal plasticity. However, if the effects of these different transmitters are also mediated by $\mathrm{PKC}$, it seems plausible that they would facilitate synaptic transmission as well.

\section{Mechanistic relationships of increased excitability and synaptic strength}

The present findings indicate that 5-HT and PKC are involved in both synaptic facilitation and increased excitability of type $B$ cells. However, they do not allow one to ascertain whether both forms of plasticity arise from a common underlying ionic conductance change or, alternatively, arise from two separate processes activated in parallel by $5-\mathrm{HT}$ and PKC (Fig. 4). On the one hand, the modulation of $\mathrm{K}^{+}$and $\mathrm{Ca}^{2+}$ currents that underlies excitability changes could also enhance transmitter release by increasing $\mathrm{Ca}^{2+}$ influx, either directly or through prolongation of individual action potentials. Supporting this possibility, initial results from our computational model (Fost and Clark, 1993) indicate that reductions in $I_{\mathrm{A}}$ and $I_{\mathrm{K}-\mathrm{Ca}}$ can produce spike broadening and synaptic facilitation as well as increases in type B ccll firing frequency. Altcrnativcly, synaptic plasticity might arise from phosphorylation of a different or additional set of proteins, resulting in functional modifications that are distinct from the excitability changes (e.g., changes in transmitter mobilization or alterations in release apparatus).

These two possibilities are not necessarily mutually exclusive, as indicated by analyses of similar questions in Aplysia mechanosensory neurons following sensitization of the gill- and siphon-withdrawal reflex and the tail-withdrawal reflex. In $A p l y$ sia sensory cells, synaptic facilitation can arise from at least two processes: first, the reduction of $5-\mathrm{HT}$-sensitive $\mathrm{K}^{+}$currents $\left(I_{\mathrm{K}-\mathrm{s}}\right.$ and $\left.I_{\mathrm{K}-\mathrm{v}}\right)$, which results in action potential broadening and enhanced transmitter release (as well as enhanced excitability) (Klein and Kandel, 1978, 1980; Siegelbaum et al., 1982; Hochner et al., 1986a; Baxter and Byrne, 1989, 1990; Goldsmith and Abrams, 1992; Hochner and Kandel, 1992; Sugita et al., 1992; Byrne et al., 1993); and a second process that is independent of action potential broadening and channel modulation (Hochner et al., 1986b; Marcus et al., 1988; Rankin and Carew, 1988; Braha et al., 1990; Dale and Kandel, 1990; Sacktor and Schwartz, 1990; Goldsmith and Abrams, 1991; Ghirardi et al., 1992; Pieroni and Byrne, 1992). Ihus, both serial and parallel pathways may be employed to effect alterations in synaptic efficacy. We arc intrigucd by this idca and plan to explore whether a similar situation occurs at Hermissenda type B to type A photoreceptor synapses.

\section{Synaptic plasticity in Hermissenda and other systems}

In a larger sense, the demonstration of synaptic plasticity in Hermissenda helps reconcile previous differences between cellular mechanisms of learning in Hermissenda and other preparations, where learning-related synaptic plasticity has been implicated (Kandel and Schwartz, 1982; Ito, 1989; Madison et al. 1991). For example, our results suggest that in Hermissenda, as in Aplysia (Klein et al., 1986; Walters, 1987; Billy and Walters, 1989; Baxter and Byrne, 1990; Mercer et al., 1991), a single neuron can encode information using two different forms of 

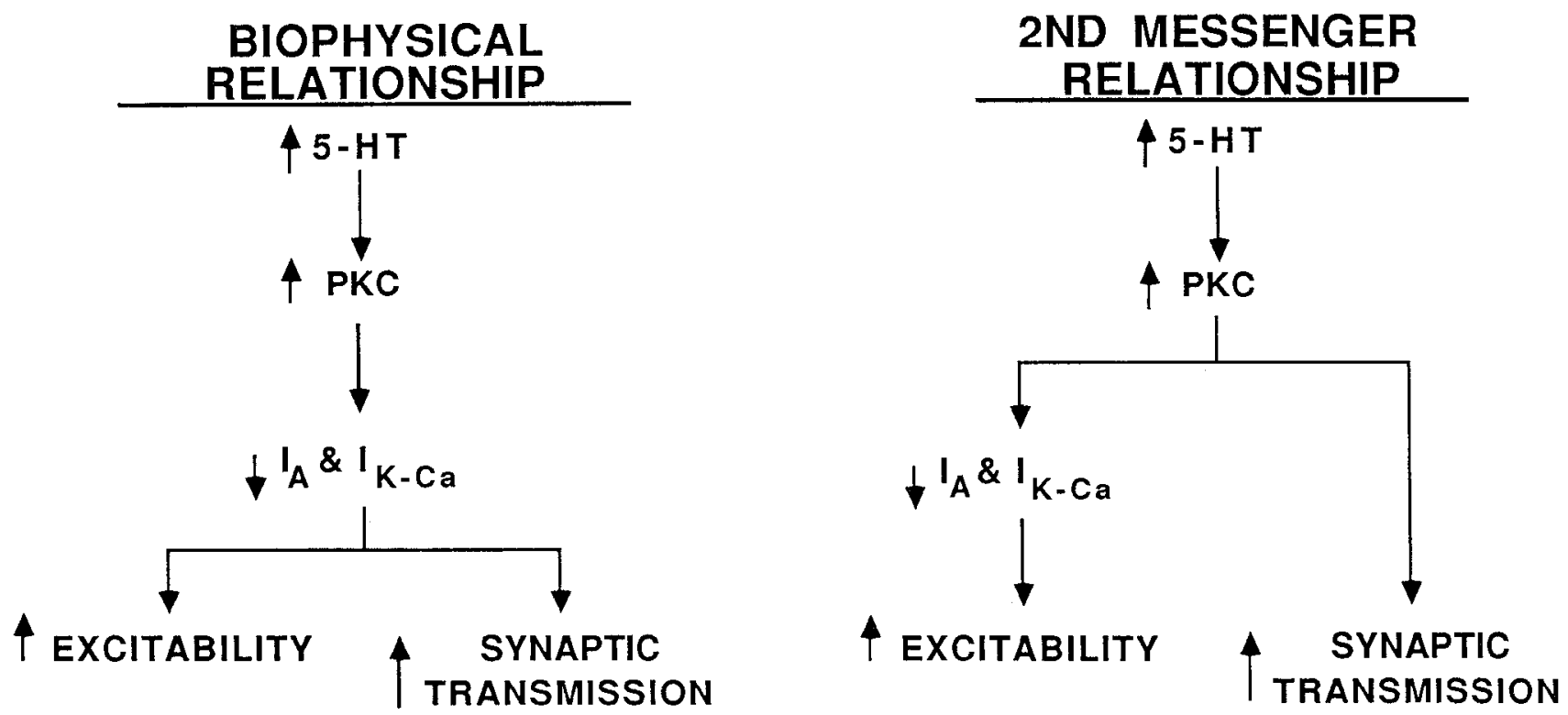

Figure 4. Possible mechanistic relationships between increased excitability and synaptic facilitation in type B photoreceptors. Serotonin (5-HT) and/or other signals are proposed to activate protein kinase $\mathrm{C}(P K C)$, which in turn elicits both enhanced excitability and synaptic facilitation. Two different potential relationships between these forms of plasticity are depicted. One possibility (BIOPHYSICAL RELATIONSHIP, left) is that PKC produces synaptic facilitation via the same ionic conductancc changes that enhance cellular excitability (e.g., a decrease in two potassium conductances, $I_{\mathrm{A}}$ and $I_{\mathrm{K}-\mathrm{Ca}}$ ), by modifying the duration or other parameters of the action potential. Alternatively (2ND MESSENGER RELATIONSHIP, right), PKC might induce synaptic facilitation via other processes, such as transmitter mobilization, not mediated by these conductance changes. The two mechanisms are not mutually exclusive, and intermediate possibilities exist.

plasticity: an increase in excitability and an increase in synaptic efficacy. Though phenotypically distinct, both forms of plasticity share aspects of a common molecular mechanism, and both operate to increase the functional output of the cell. It is interesting to note that in both Hermissenda and Aplysia, these two forms of neuronal plasticity co-occur in single cells even though there are a number of important distinctions between the systems. Compared with plasticity in Aplysia sensory neurons, plasticity in Hermissenda type B photoreceptors involves a different sensory modality (light rather than touch), inhibitory rather than excitatory synaptic potentials, the modification of different types of $\mathrm{K}^{+}$currents $\left(I_{\mathrm{A}}\right.$ and $I_{\mathrm{K}-\mathrm{Ca}}$ vs $I_{\mathrm{K}-\mathrm{s}}$ and $\left.I_{\mathrm{K}-\mathrm{v}}\right)$, and differences in second-messenger systems that mediate the changes (primarily PKC, rather than the cAMP-dependent kinase and PKC). The dual modulation of synaptic strength and neuronal excitability that occurs in both preparations is thus an important common feature that transcends the particular differences. Such convergence reinforces the belief that some general principles regarding cellular mechanisms of learning are beginning to emerge.

\section{References}

Alkon DL (1974) Associative training of Hermissenda. J Gen Physiol 64:70-84.

Alkon DL (1976) Signal transformation with pairing of sensory stimuli. J Gen Physiol 67:197-211.

Alkon DL (1979) Voltage-dependent calcium and potassium ion conductances: a contingency mechanism for an associative learning model. Science 205:810-816.

Alkon DL (1984) Calcium-mediated reduction of ionic currents: a biophysical memory trace. Science 226:1037-1045.

Alkon DL, Nelson TJ (1990) Specificity of molecular changes in neurons involved in memory storage. Fed Proc 4:1567-1576.

Alkon DL, Lederhendler I, Shoukimas J (1982) Primary changes of membrane currents during retention of associative learning. Science 215:693-695.

Alkon DL, Sakakibara M, Forman R, Harrigan J, Lederhendler I, Farley
J (1985) Reduction of two voltage-dependent $\mathrm{K}^{+}$currents mediates retention of a learned association. Behav Neural Biol 44:278-300.

Alkon DL, Kubota M, Neary JT, Naito S, Coulter D, Rasmussen H (1986) C-kinase activation prolongs $\mathrm{Ca}^{2+}$-dependent inactivation of $\mathrm{K}^{+}$currents. Biochem Biophys Res Commun 134:1245-1253 [published erratum Biochem and Biophys Res Commun 140:774].

Alkon DL, Naito S, Kubota M, Chen C, Bank B, Smallwood J, Gallant $\mathrm{P}$, Rasmussen $\mathrm{H}$ (1988) Regulation of Hermissenda $\mathrm{K}^{+}$channels by cytoplasmic and membrane associated C-kinase. J Neurochem 51 : 903-917.

Alkon DL, Ikeno H, Dworkin J, McPhie DL, Olds JL, Lederhendler I, Matzel L, Schreurs BG, Kuzirian A, Collin C, Yamoah E (1990) Contraction of branching volume: an anatomic correlate of Pavlovian conditioning. Proc Natl Acad Sci USA 87:1611-1614.

Alkon DL, Sánchez-Andrés JV, Ito E, Oka K, Yoshioka T, Collin C (1992) Long-term transformation of an inhibitory into an excitatory GABAergic synaptic response. Proc Natl Acad Sci USA 89:1186211866.

Auerbach S, Grover L, Farley J (1989) Neurochemical and immunocytochemical studies of serotonin in the Hermissenda central nervous system. Brain Res Bull 22:353-361.

Baxter DA, Byrne JH (1989) Serotonergic modulation of two potassium currents in the pleural sensory neurons of Aplysia. J Neurophysiol 62:665-679.

Baxter DA, Byrne JH (1990) Differential effects of cAMP and serotonin on membrane current action potential duration, and excitability in somata of pleural sensory neurons of Aplysia. J Neurophysiol 64:978-990.

Billy AJ, Walters ET (1989) Long-term expansion and sensitization of mechanosensory receptive fields in Aplysia support an activitydependent model of whole-cell plasticity. J Neurosci 9:1254-1262.

Braha O, Dale N, Hochner B, Klein M, Abrams TW, Kandel ER (1990) Second messengers involved in the two processes of presynaptic facilitation that contribute to sensitization and dishabituation in Aplysia sensory neurons. Proc Natl Acad Sci USA 87:2040-2044.

Byrne JH (1987) Cellular analysis of associative learning. Physiol Rev 67:329-439.

Byrne JH, Zwartjes R, Homayouni R, Critz SD, Eskin A (1993) Roles of second messenger pathways in neuronal plasticity and in learning and memory. Insights gained from Aplysia. Adv Second Messenger Phosphoprotein Res 27:47-108. 
Carew TJ, Sahley CL (1986) Invertebrate learning and memory: from behavior to molecules. Annu Rev Neurosci 9:435-487.

Carew TJ, Hawkins RD, Abrams TW, Kandel ER (1984) A test of Hebb's postulate at identified synapses which mediate classical conditioning in Aplysia. J Neurosci 4:1217-1224.

Cheyette BN, Farley J (1989) Localization of 5-HT containing neurons which modulate Hermissenda type B cell excitability. Soc Neurosci Abstr 15:1284

Clark GA, Schuman EM (1992) Snails' talcs: initial comparisons of synaptic plasticity underlying learning in Hermissenda and Aplysia. In: Neuropyschology of memory, 2d ed (Squire LR, Butters N, eds), pp 588-602. New York: Guilford.

Collin C, Ikeno H, Harrigan JF, Lederhendler I, Alkon DL (1988) Sequential modification of membrane currents with classical conditioning. Biophys J 54:955-960.

Crow T (1983) Conditioned modification of locomotion in Hermissenda crassicornis: analysis of time-dependent associative and nonassociative components. J Neurosci 3:2621-2628.

Crow T (1988) Cellular and molecular analysis of associative learning and memory in Hermissenda. Trends Neurosci 11:136-142

Crow T, Alkon DL (1978) Retention of an associative behavioral change in Hermissenda. Science 201:1239-1241.

Crow T, Alkon DL (1980) Associative behavioral modification in Hermissenda: cellular correlates. Science 209:412-414.

Crow T, Bridge MS (1985) Serotonin modulates photoresponses in Hermissenda type-B photoreceptors. Neurosci Letl 60:83-88.

Crow T, Forrester J (1986) Light paired with serotonin mimics the effect of conditioning on phototactic behavior of Hermissenda. Proc Natl Acad Sci USA 83:7975-7978.

Crow T, Forrester J (1991) Light paired with serotonin in vivo produces both short- and long-term enhancement of generator potentials of identified B-photoreceptors in Hermissenda. J Neurosci 11:608-617.

Crow T, Offenbach N (1983) Modification of the initiation of locomotion in Hermissenda: behavioral analysis. Brain Res 271:301-310

Crow T, Forrester J, Williams M, Waxham MN, Neary JT (1991) Down-regulation of protein kinase $\mathrm{C}$ blocks 5-HT-induced enhancement in Hermissenda B photoreceptors. Neurosei Lett 121:107. 110.

Dale N, Kandel ER (1990) Facilitatory and inhibitory transmitters modulate spontaneous transmitter release at cultured Aplysia sensorimotor synapses. J Physiol (Lond) 421:203-222.

Etcheberrigaray R, Matzel LD, Lederhendler II, Alkon DL (1992) Classical conditioning and protein kinase $\mathrm{C}$ activation regulate the same single potassium channel in Hermissenda crassicornis photoreceptors. Proc Natl Acad Sci USA 89:7184-7188.

Falk-Vairant J, Crow T (1992) Intracellular injections of BAPTA block induction of enhancement in Hermissenda type B-photoreceptors. Neurosci Lett 147:48-48.

Farley J (1986) Cellular mechanisms of causal detection in a mollusk. In: Neural mechanisms of conditioning (Alkon DL, Woody CD, eds), pp 19-54. New York: Plenum.

Farley J (1988) Associative training results in persistent reductions in a calcium-activated potassium current in Hermissenda type B photoreceptors. Behav Neurosci 102:784-802

Farley J, Alkon DL (1982) Associative and behavioral change in $\mathrm{Her}$ missenda: consequences of nervous system orientation for light- and pairing specificity. J Neurophysiol 48:785-807.

farley J, Alkon DL (1987) In vitro associative conditioning of Hermissenda: cumulative depolarization of type B photoreceptors and short-term associative behavioral change. J Neurophysiol 57:16391668.

Farley J, Auerbach S (1986) Protein kinase C activation induces conductance changes in Hermissenda photoreceptors like those seen in associative learning. Nature 319:220-223 [published erratum Nature 324:702].

Farley J, Schuman E (1991) Protein kinase C inhibitors prevent induction and continued expression of cell memory in Hermissenda type B photoreceptors. Proc Natl Acad Sci USA 88:2016-2020.

Farley J, Wu R (1989) Serotonin modulation of Hermissenda type B photoreceptor light responses and ionic currents: implications for mechanisms underlying associative learning. Brain Res Bull 22:335351.

Farley J, Richards WG, Grover LM (1990) Associative learning changes intrinsic to Hermissenda type A photoreceptors. Behav Neurosci 104: $135-152$.

Forrester J, Crow T (1988) Protein kinase C inhibition prevents short- term but not long-term light-5-HT-induced enhancement of generator potentials in Hermissenda. Soc Neurosci Abstr 14:839.

Forrester J, Crow T (1989) Kinase inhibitors do not reverse short- or long-term enhancement of light responses in identified Hermissenda B-photoreceptors. Soc Neurosci Abstr 15:1284.

Fost JW, Clark GA (1993) Computational analysis of contributions of $\mathrm{K}^{+}$currents to learning-dependent changes in Hermissenda type B photoreceptors. Soc Neurosci Abstr 19:580.

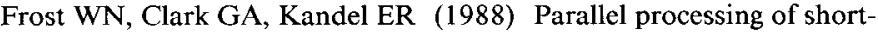
term memory for sensitization in Aplysia. J Neurobiol 19:297-334.

Frysztak RJ, Crow T (1991) Correlates of conditioning in pairs of identified type $\mathrm{A}$ and $\mathrm{B}$ photoreceptors in Hermissenda: effects of adaptation, light intensity and synaptic interactions. Soc Neurosci Abstr 17:1054.

Frysztak RJ, Crow T (1994) Enhancement of type B and type A photoreceptor inhibitory synaptic connections in conditioned Hermissenda. J Neurosci 14:1245-1250.

Ghirardi M, Braha O, Hochner B, Montarolo PG, Kandel ER, Dale N (1992) Roles of PKA and PKC in facilitation of evoked and spontaneous transmitter release at depressed and nondepressed synapses in Aplysia sensory neurons. Neuron 9:479-489.

Goh Y, Alkon DL (1984) Sensory, interneuronal, and motor interactions within the Hermissenda visual pathway. J Neurophysiol 52: 156-169.

Goh Y, Lederhendler I, Alkon DL (1985) Input and output changes of an identified neural pathway are correlated with associative learning in Hermissenda. J Neurosci 5:536-543.

Goldsmith BA, Abrams TW (1991) Reversal of synaptic depression by serotonin at Aplysia sensory neuron synapses involves activation of adenylyl cyclase. Proc Natl Acad Sci USA 88:9021-9025.

Goldsmith BA, Abrams TW (1992) cAMP modulates multiple $\mathrm{K}^{+}$ currents, increasing spike duration and excitability in Aplysia sensory neurons. Proc Natl Acad Sci USA 89:11481-11485.

Grover IM Farley J, Auerbach SB (1989) Serotonin involvement during in vitro conditioning of Hermissenda. Brain Res Bull 22:363372.

Hawkins RD, Abrams TW, Carew TJ, Kandel ER (1983) $\Lambda$ cellular mechanism of classical conditioning in Aplysia: activity-dependent amplification of presynaptic facilitation. Science 219:400-405.

Hawkins RD, Clark GA, Kandel ER (1987) Cell biological studies of learning in simple vertebrate and invertebrate systems. In: Handbook of physiology, Sect 1, The nervous system, Vol V, Higher functions of the nervous system, Pt 1 (Mountcastle VB, Plum F, Geiger SR, eds), pp 25-83. Bethesda, MD: American Physiological Society.

Heldman E, Alkon DL (1978) Neurotransmitter synthesis in the nervous system of the mollusc Hermissenda. Comp Biochem Physiol 59: $117-125$

Hochner B, Kandel ER (1992) Modulation of a transient $\mathrm{K}^{+}$current in the pleural sensory neurons of Aplysia by serotonin and cAMP: implications for spike broadening. Proc Natl Acad Sci USA 89:1147611480.

Hochner B, Klein M, Schacher S, Kandel ER (1986a) Action potential duration and the modulation of transmitter release from the sensory neurons of Aplysia in presynaptic facilitation and behavioral sensitization. Proc Natl Acad Sci USA 83:8410-8414.

Hochner B, Klein M, Schacher S, Kandel ER (1986b) Additional component in the cellular mechanism of presynaptic facilitation contributes to behavioral dishabituation in Aplysia. Proc Natl Acad Sci USA 83:8794-8798.

Hodgson TM, Crow T (1992) Cellular correlates of classical conditioning in identified light responsive pedal neurons of Hermissenda crassicornis. Brain Res 570:267-271.

Ito M (1989) Long-term depression. Annu Rev Neurosci 12:85-102. Kandel ER, Schwartz JH (1982) Molecular biology of learning: modulation of transmitter release. Science 218:433-443.

Klein M, Kandel ER (1978) Presynaptic modulation of a voltagedependent $\mathrm{Ca}^{2+}$ current: mechanism for behavioral sensitization. Proc Natl Acad Sci USA 75:3512-3516.

Klein M, Kandel ER (1980) Mechanism of calcium current modulation underlying presynaptic facilitation and behavioral sensitization in Aplysia. Proc Natl Acad Sci USA 77:6912-6916.

Klein M, Hochner B, Kandel ER (1986) Facilitatory transmitters and cAMP can modulate accommodation as well as transmitter release in Aplysia sensory neurons: evidence for parallel processing in a single cell. Proc Natl Acad Sci USA 83:7994-7998. 
Land PW, Crow T (1985) Serotonin immunoreactivity in the circumesophageal nervous system of Hermissenda crassicornis. Neurosci Lett 62:199-205.

Lederhendler II, Alkon DL (1987) Associatively reduced withdrawal from shadows in Hermissenda: a direct behavioral analog of photoreceptor responses to brief light steps. Behav Neural Biol 47:227249.

Lederhendler II, Gart S, Alkon DL (1986) Classical conditioning of Hermissenda: origin of a new response. J Neurosci 6:1325-1331.

Madison DV, Malenka RC, Nicoll RA (1991) Mechanisms underlying long-term potentiation of synaptic transmission. Annu Rev Neurosci 14:379-397.

Marcus EA, Nolen TG, Rankin CH, Carew TJ (1988) Behavioral dissociation of dishabituation, sensitization, and inhibition of $A p l y$ sia. Science 241:210-213.

Matzel LD, Alkon DL (1991) GABA-induced potentiation of neural excitability occurs during contiguous pairings with intracellular calcium elevation. Brain Res 554:77-84.

Matzel LD, Lederhendler I, Alkon DL (1990a) Regulation of shortterm associative memory by calcium-dependent protein kinase. J Neurosci 10:2300-2307.

Matzel LD, Schreurs BG, Alkon DL (1990b) Pavlovian conditioning of distinct components of Hermissenda's responses to rotation. Behav Neural Biol 54:131-145.

Matzel LD, Collin C, Alkon DL (1992a) Biophysical and behavioral correlates of memory storage, degradation, and reactivation. Behav Neurosci 106:954-963.

Matzel LD, Rogers RF, Fass DM (1992b) Calcium transients, not accumulation, induce biophysical correlates of learning in Hermissenda. Soc Neurosci Abstr 18:15.

McPhie DL, Matzel LD, Olds JL, Lester DS, Kuzirian AM, Alkon DL (1993) Cell specificity of molecular changes during memory storage. J Neurochem 60:646-651.

Mercer AR, Emptage NJ, Carew TJ (1991) Pharmacological dissociation of modulatory effects of serotonin in Aplysia sensory neurons. Science 254:1811-1813.

Neary JT, Crow T, Alkon DL (1981) Change in a specific phosphoprotein band following associative learning in Hermissenda. Nature 293:658-660.

Neary JT, Naito S, DeWeer A, Alkon DL (1986) $\mathrm{Ca}^{2+} /$ diacylglycerolactivated, phospholipid-dependent protein kinase in the Hermissenda CNS. J Neurochem 47:1405-1411.

Nelson TJ, Colin C, Alkon DL (1990) Isolation of a Grotein that is modified by learning and reduces potassium currents in Hermissenda. Science 247:1479-1483.

Oka K, Ito E, Collin C, Yoshioka T, Alkon DL (1992) GABA-induced intracellular $\mathrm{Ca}^{2+}$ responses of the $\mathrm{B}$ photoreceptors of Hermissenda. Soc Neurosci Abstr 18:15.

Pieroni JP, Byrne JH (1992) Differential effects of serotonin, FMRFamide, and small cardioactive peptide on multiple distributed processes modulating sensorimotor synaptic transmission in Aplysia. J Neurosci 12:2633-2647.
Rankin CH, Carew TJ (1988) Dishabituation and sensitization emcrge as separate processes during development in Aplysia. J Neurosci 8:197 211.

Richards WG, Farley J (1987) Motor correlates of phototaxis and associative learning in Hermissenda crassicornis. Brain Res Bull 19: 175-189.

Rogers RF, Fass DM, Specht SM, Matzel LD (1992) Contrasting effects of known neurotransmitters on visual-vestibular responses in $\mathrm{Her}$ missenda. Soc Neurosci Abstr 18:530.

Ruegg UT, Burgess GM (1989) Staurosporine, K-252 and UCN-01: potent but nonspecific inhibitors of protein kinases. Trends Pharmacol Sci 10:218-220.

Sacktor TC, Schwartz JH (1990) Sensitizing stimuli cause translocation of protein kinase $\mathrm{C}$ in Aplysia sensory neurons. Proc Natl Acad Sci USA 87:2036-2039.

Sakakibara M, Collin C, Kuzirian A, Alkon DL, Heldman E, Naito S, Lederhendler I (1987) Effect of $\alpha_{2}$-adrenergic agonists and antagonists on photoreceptor membrane currents. J Neurochem 48:405416.

Schacher S, Castellucci VF, Kandel ER (1988) cAMP evokes longterm facilitation in Aplysia sensory neurons that requires new protein synthesis. Science 240:1667-1669.

Schuman EM, Clark GA (1990) Hermissenda photoreceptors exhibit synaptic facilitation as well as enhanced excitability. Soc Neurosci Abstr 16:21

Siegelbaum SA, Camardo JS, Kandel ER (1982) Serotonin and cyclic AMP close single $\mathrm{K}^{+}$channels in Aplysia sensory neurons. Nature 299:413-417.

Sugita S, Goldsmith JR, Baxter DA, Byrne JH (1992) Involvement of protein kinase $\mathrm{C}$ in serotonin-induced spike broadening and synaptic facilitation in sensorimotor connections of Aplysia. J Neurophysiul 68:643-651.

Tabata M, Alkon DL (1982) Positive synaptic feedback in visual system of nudibranch mollusk Hermissenda crassicornis. J Neurophysiol 48:174-191.

Tamaoki T, Nomoto H, Takahashi I, Kato Y, Morimoto M, Tomita F (1986) Staurosporine, a potent inhibitor of phospholipid/Ca+ $/ \mathrm{Ce}^{+}$ pendent protein kinase. Biochem Biophys Res Commun 135:397402.

Tesauro G (1988) A plausible neural circuit for classical conditioning without synaptic plasticity. Proc Natl Acad Sci USA 85:2830-2833.

Walters ET (1987) Multiple sensory neuronal correlates of site-specific sensitization in Aplysia. J Neurosci 7:408-417.

Walters ET, Byrne JH (1983) Associative conditioning of single sensory neurons suggests a cellular mechanism for learning. Science 219 : 405-408

Werness SA, Fay SD, Blackwell KT, Vogl TP, Alkon DL (1992) Associative learning in a network model of Hermissenda crassicornis. I. Theory. Biol Cybern 68:125-133.

West A, Barnes E, Alkon DL (1982) Primary changes of voltage responses during retention of associative learning. J Neurophysiol 48: 1243-1255. 